\title{
面内に圧縮力を受ける樹脂サンドイッチ鋼板の強度に関する研究 STRENGTH OF STEEL-POLYMER-STEEL LAMINATED SANDWICH PLATE IN COMPRESSION
}

\author{
岡田久志*, 橋本篤秀**, 緑川光正*** \\ Hisayuki OKADA, Atuhide HASHIMOTO and Mitumasa MIDORIKAWA
}

\begin{abstract}
The purpose of this paper is to investigate the compressive strength of steel-polymer-steel laminated sandwich plate, which can be influenced by the shearing behavior of the core polymer, According to analytical investigation, simplified equations are derived to estimate the buckling strength of laminated plates, of which 4 edges are simply supported, under compressive force on 2 edges. Then introducing of the newly proposed parameter on width-thickness ratio makes the estimation of the ultimate strength easy. These analytical results showed good agreement with experimental results.
\end{abstract}

Keywords : steel-polymer-steel laminated sandweich plate, shearing behavior of polymer, buckling strength, ultimate strength, compression tests, polymer thickness

樹脂サンドイッチ鋼板，樹脂層のせん断変形，座屈強度，後座屈強度，圧縮載荷実験， 樹脂厚

\section{1. 序}

2 枚の薄鋼板の中間に樹脂層を設けて複合鋼板とした 樹脂サンドイッチ鋼板は，高い制振性能を有する新しい 材料として，あるいは軽量化された鋼板として，自動車， 家電製品に利用され始めている。最近では, 制振性能を 活用して,建築分野においての利用も検討されつつある。 これに伴って, 平板に近い状態での利用から屋根用折板 や鋼製床など次第に断面形状が複雑化して, 制振性能の みならず，加工性や耐荷性能も要求されるようになって きている。

樹脂サンドイッチ鋼板は，板厚方向に機械的性質の異 なる樹脂層が存在しているので, 樹脂層にせん断変形が 生じる面外変形挙動に対しては, 剛性が低下し, 単一鋼 板には見られない複雑な性状を示すものと考えられる。 このような変形挙動では，せん断変形を考えないKirchihoff-Love の仮定に基づく解析法では再現すること ができない。

吉田・本屋敷ら”は, 樹脂層のせん断変形の影響が顕 著になる 3 点曲げを取り上げ，樹脂のせん断変形を考慮 した弾塑性解析を行って, 曲げ剛性低下に及ぼす樹脂層 のヤング率, 厚さ,スパンの効果等について考察してい
る。また, 実験値とも比較し解析法の妥当性を検証して いる。牧野内 ${ }^{21}$ は, 弾塑性有限要素法によるU曲げ加工 解析法を提案し，牧野内・吉田ら ${ }^{3)}$ は，その解析法を用 いて曲げ成形過程のシミュレーションを行っている。こ れらは，いずれも 1 方向に面外曲げを受ける樹脂サンド イッチ鋼板を対象としたものである。

1 枚の平板としてではなく, 折板のように薄板で構成 された断面部材では，構成板要素が面内力によって局部 的に生じる板座屈，すなわち局部座屈が耐荷力に大きな 影響を与える事は周知のとおりである。樹脂サンドイッ チ鋼板を用いたこのような薄肉断面部材の耐荷力に関す る研究は，幅厚比の小さい断面部材を対象とした実験的 研究4),5)がわずか行われているにすぎず，面内の圧縮力 によって生ずる樹脂サンドイッチ鋼板の座屈挙動に関す る基礎的研究は，今のところ見あたらない。

本研究は，薄板の樹脂サンドイッチ鋼板を用いた構造 部材が局部座屈で耐力が決定されるような場合の耐荷力 評価を行うための基礎的な研究として行うもので,まず， 面内に圧縮力を受ける 4 辺単純支持された樹脂サンド イッチ鋼板に関して，樹脂層のせん断変形を考慮した板 座屈解析を行い，弹性座屈強度評価式を導く。また，樹
* 愛知工業大学建築工学科 助教授 $\cdot$ 工博

**葉工業大学建築科 教授・工博

*** 建設省建築研究所·工博
Assoc. Prof., Dept. of Architectural Engineering, Aichi Institute of Technorogy, Dr. Eng.

Prof., Dept. of Architecture, Chiba Institute of Technorogy, Dr. Eng. Building Reserch Institute, the Dept. of Construction, Dr. Eng. 
脂サンドイッチ鋼板の幅厚比に対して新しいパラメー ターを導入することによって, 後座屈強度の評価式を与 える。これら強度評価式の妥当性は, 樹脂サンドイッチ 鋼板の面内に圧縮力を加える実験により確認される。さ らに，樹脂サンドイッチ鋼板の座屈強度・後座屈強度に 与える樹脂層のせん断剛性・樹脂厚・幅厚比・アスペク ト比の影響等について考察する。

\section{2. 座属解析}

\section{1 弾性座屈強度}

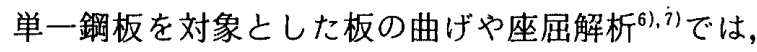
ほとんゼが Kirchihoff-Love の仮定に基づいており，せ ん断変形は考慮されていない。しかし，樹脂サンドイッ 于鋼板の座屈解析では, 樹脂層におけるせん断変形を無 視することが出来ない。そこで，樹脂サンドイッチ鋼板 の座屈解析にあたり，本報では次の仮定を設ける。

(1) 鋼板部分では, Kirchihoff-Love の仮定(Fig.1(a) 参照）が成立する。

（2）樹脂層に対しては，Timochenko 梁の考え方に基 づき (Fig.1(b) 参照)，2 方向の面外曲げによって生じ るせん断変形を考虑する。

（3）樹脂層における面外方向せん断力によるせん断ひ ずみ度は，厚さ方向に対して一様に分布するものと考え る。

（4）鋼板と樹脂層との接着は，完全であり，接着面に おいてずれも分離も生じないものとする。

またこここで対象とする樹脂サンドイッチ鋼板は，樹脂 層を挟む 2 枚の表層にある鋼板が等厚なものに限定す

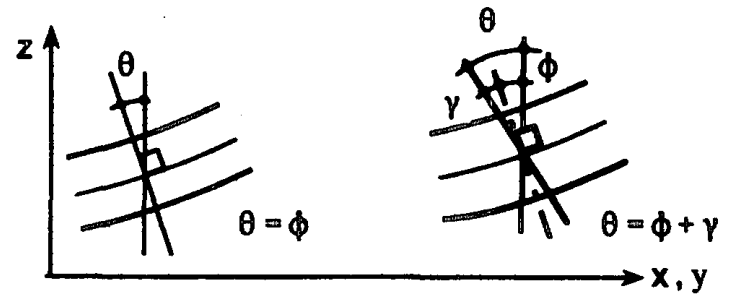

(a) Kirchihoff-Love の仮定 （b） Timochenkoのはり

Fig. 1 せん断変形に関する解析モデル

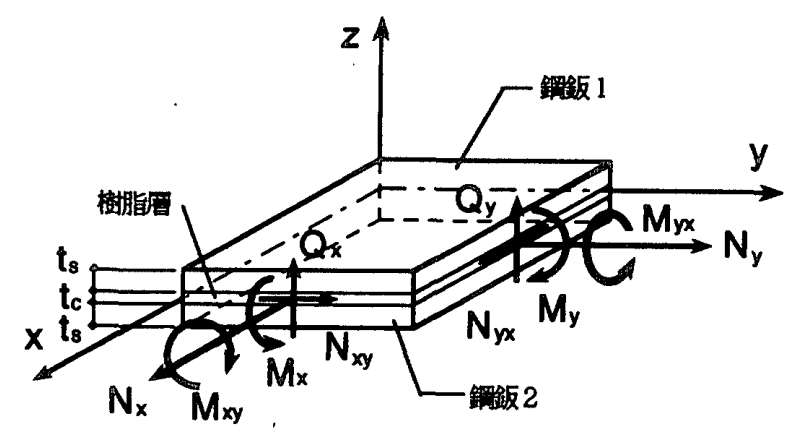

Fig. 2 樹脂サンドイッチ鋼鈑に作用する応力
る。

Fig. 2のような面外曲げおよび面内力を受ける樹脂サ ンドイッチ鋼板の面外 $(z$ 軸方向) 変形量を $w(x, y)$ で, また, 面内変形量を次式で与える。

$$
\left.\begin{array}{l}
u(x, y, z)=u_{0}(x, y)+\alpha(x, y) z \\
v(x, y, z)=v_{0}(x, y)+\beta(x, y) z
\end{array}\right\}
$$

ここで, $u, v$ は, $x, y$ 軸方向の変形量, $u_{0}, v_{0}$ は $z=$ 0 (樹脂層中央面）における変形量である。

これより，変形とひずみ度の関係ならびに（2）の仮定 から，樹脂層における $\alpha$ および $\beta$ は

$$
\left.\begin{array}{l}
\alpha(x, y)=\frac{\partial w}{\partial x}+\gamma_{x z} \\
\beta(x, y)=-\frac{\partial w}{\partial y}+\gamma_{y z}
\end{array}\right\}
$$

で与えられる。ここで， $\gamma_{x z}, \gamma_{y z}$ は，樹脂層の面外方向 に生ずるせん断ひずみ度である。また，表層の鋼板につ いては, Kirchihoff-Love の仮定に従うので，

$$
\left.\begin{array}{l}
\alpha(x, y)=-\frac{\partial w}{\partial x} \\
\beta(x, y)=-\frac{\partial w}{\partial y}
\end{array}\right\}
$$

となる。なお, Fig. 1 中の $x$ 軸に対する $\Phi, \gamma$ は, $-\frac{\partial w}{\partial x}$, $\gamma_{x z}$ に，また $y$ 軸に対する $\Phi, \gamma$ は, $-\frac{\partial w}{\partial y}, \gamma_{y z}$ に対応 する。

その結果, 樹脂サンドイッチ鋼板を構成している各層 のひずみ度成分 $\varepsilon_{x}, \varepsilon_{y}, \gamma_{x y}$ は，次式で与えられる。 樹脂層：

$$
\begin{aligned}
& \varepsilon_{x}=\varepsilon_{x 0}-z\left(\frac{\partial^{2} w}{\partial x^{2}}-\frac{\partial \gamma_{x z}}{\partial x}\right) \\
& \varepsilon_{y}=\varepsilon_{y 0}-z\left(\frac{\partial^{2} w}{\partial y^{2}}-\frac{\partial \gamma_{x z}}{\partial y}\right) \\
& \gamma_{x y}=\gamma_{x y 0}-z\left(2 \frac{\partial^{2} w}{\partial x \partial y}-\frac{\partial \gamma_{x z}}{\partial y}-\frac{\partial \gamma_{y z}}{\partial x}\right)
\end{aligned}
$$

鋼板 1, 2：

$$
\begin{aligned}
& \varepsilon_{x}=\varepsilon_{x 0}-z \frac{\partial^{2} w}{\partial x^{2}} \pm \frac{t_{c} \partial \gamma_{x z}}{2 \partial x} \\
& \varepsilon_{y}=\varepsilon_{y 0}-z \frac{\partial^{2} w}{\partial y^{2}} \pm \frac{t_{c} \partial \gamma_{y z}}{2 \partial y} \\
& \gamma_{x y}=\gamma_{x y 0}-2 z \frac{\partial^{2} w}{\partial x \partial y} \pm \frac{t_{c}}{2}\left(\frac{\partial \gamma_{x z}}{\partial y}+\frac{\partial \gamma_{y z}}{\partial x}\right)
\end{aligned}
$$

ここで, 複合符号は, Fig. 2 に示す鋼板 1 に対して正, 鋼板 2 に対して負をとる。 $\varepsilon_{x 0}, \varepsilon_{y 0}, \gamma_{x y 0}$ は， $z=0$ (樹脂 層中央面）におけるひずみ度成分， $t_{c}$ は樹脂厚である。

樹脂サンドイッチ鋼板が面内応力によって座屈し，横 たわみを生じる時, 曲げ変形によるひずみエネルギー $U_{b}$ は, (3) 式と応力度・ひずみ度の関係から次の式で 与えられる。 


$$
\begin{aligned}
U_{b}=\int & \int \Delta U_{b} d x d y \\
\Delta U_{b}= & D_{11}\left\{\left(\frac{\partial^{2} w}{\partial x^{2}}\right)^{2}+2 \nu_{s}\left(\frac{\partial^{2} w}{\partial x^{2}}\right)\left(\frac{\partial^{2} w}{\partial y^{2}}\right)\right\} \\
& +D_{11 D}\left(\frac{\partial^{2} w}{\partial x \partial y}\right)^{2}+2 D_{12}\left\{\left(\frac{\partial^{2} w}{\partial x^{2}}+\frac{\partial^{2} w}{\partial y^{2}}\right)\right. \\
& \cdot\left(\frac{\partial^{2} \gamma_{x z}}{\partial x}+\frac{\partial^{2} \gamma_{y z}}{\partial y}\right)-\left(1-\nu_{s}\right) \\
& \left.\cdot\left(\frac{\partial^{2} w}{\partial x^{2}} \frac{\partial^{2} \gamma_{y z}}{\partial y}+\frac{\partial^{2} w}{\partial y^{2}} \frac{\partial^{2} \gamma_{x z}}{\partial x}\right)\right\} \\
& +D_{12 D} \frac{\partial^{2} w}{\partial x \partial y}\left(\frac{\partial \gamma_{x z}}{\partial y}+\frac{\partial \gamma_{y z}}{\partial x}\right) \\
& +D_{13}\left\{\left(\frac{\partial \gamma_{x z}}{\partial x}+\frac{\partial \gamma_{y z}}{\partial y}\right)^{2}\right. \\
& \left.\cdot{ }^{2}\left(1-\nu_{s}\right) \frac{\partial \gamma_{x z}}{\partial x} \frac{\partial \gamma_{y z}}{\partial y}\right\} \\
& D_{13 D}\left\{\left(\frac{\partial \gamma_{x z}}{\partial y}+\frac{\partial \gamma_{y z}}{\partial x}\right)^{2}-2\left(1-\nu_{s}\right) \frac{\partial \gamma_{x z}}{\partial y} \frac{\partial \gamma_{y z}}{\partial x}\right\} \\
+ & D_{21}\left(\gamma_{x z}^{2}+\gamma_{y z}^{2}\right)
\end{aligned}
$$

ここに,

$$
\begin{aligned}
& D_{0}=E_{s} T^{3} /\left\{12\left(1-\nu_{s}^{2}\right)\right\} \\
& D_{11}=D_{0}\left\{1-(1-\tilde{E}) \beta^{3}\right\}, \\
& D_{11 D}=2\left(1-\nu_{s}\right) D_{0}\left\{1-(1-\tilde{G}) \beta^{3}\right\} \\
& D_{12}=-3 D_{0} \beta\left\{1-(1-2 \tilde{E} / 3) \beta^{2}\right\} / 2 \\
& D_{12 D}=-3\left(1-\nu_{s}\right) D_{0} \beta\left\{1-(1-2 \tilde{G} / 3) \beta^{2}\right\} / 2 \\
& D_{13}=3 D_{0} \beta^{2}\{1-(1-\tilde{E} / 3) \beta\}, \\
& D_{13 D}=3\left(1-\nu_{s}\right) D_{0} \beta^{2}\{1-(1-\tilde{G} / 3) \beta\} / 2 \\
& D_{21}=G_{c} \beta T \quad \nu_{s}: \text { 鋼のポアソン比 } \\
& \beta=t_{c} / T, T=2 t_{s}+t_{c} \text { (全厚), } \tilde{E}=E_{c} / E_{s} ; \\
& \tilde{G}=G_{c} / G_{s}
\end{aligned}
$$

$E_{s}, E_{c}$ : 鋼および樹脂のヤング係数

$G_{s}, G_{c}$ : 鋼および樹脂のせん断弾性係数

また，面内の初期応力による仕事 $V$ は，

$$
\left.\begin{array}{l}
V=\iint \Delta V d x d y \\
\Delta V=\frac{1}{2}\left\{N_{x}\left(\frac{\partial w}{\partial x}\right)^{2}+N_{x y}\left(\frac{\partial w}{\partial x}\right)\left(\frac{\partial w}{\partial y}\right)+N_{y}\left(\frac{\partial w}{\partial y}\right)^{2}\right\}
\end{array}\right\}
$$

ここに， $N_{x}, N_{x y}, N_{y}$ は，面内応力を表す。

座屈支配方程式は, (4), (5) 式と, 最小ポテンシャ ルエネルギー原理を用いて，

$$
\delta \Pi=\delta\left(U_{b}-V\right)=0
$$

から, $w, \gamma_{x z}, \gamma_{y z}$ を変数とする連立偏微分方程式とし て導かれる。

ここでは，レイリー・リッツ法を用いて，Fig.3に示 すような面内に圧縮力 $N_{x}$ のみを受ける周辺単純支持さ れた樹脂サンドイッチ鋼板の弾性座屈強度の評価式を求 める。なお，樹脂サンドイッチ鋼板の 4 辺における樹脂 層のせん断変形は, 拘束されていないものとする。この

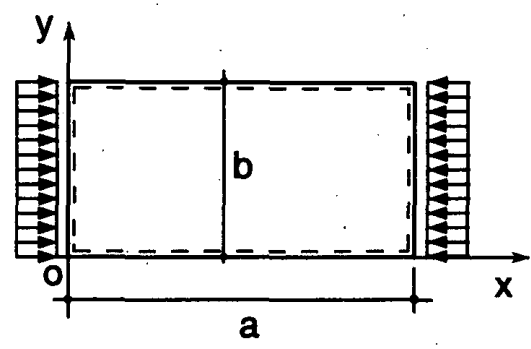

Fig. 34 辺が単純支持された面内圧縮力を受ける樹脂サシド イッチ鋼鈑

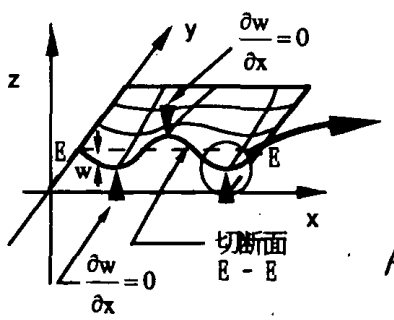

(a)

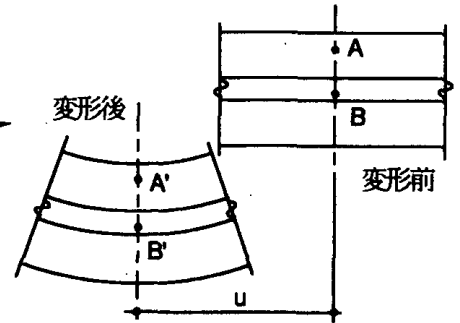

(b)
Fig. 4 坐屈モードが $\frac{\partial w}{\partial x}=0$ となる位置における変形状態

ような支持状態にある板の境界条件は， $x=0, a$ 上の辺 において,

$$
w=0 \text { かつ } \gamma_{y z}=0
$$

また， $\varepsilon_{y}=0$ であることに留意すると，

$$
M_{x}=\int \sigma_{x} z d x=D_{11} \frac{\partial^{2} w}{\partial x^{2}}+D_{12} \frac{\partial \gamma_{x z}}{\partial x}=0
$$

同様に, $y=0, b$ 上の辺において

$$
\begin{aligned}
& w=0, \quad \gamma_{x z}=0 \text { かつ } \\
& M_{y}=\int \sigma_{y} z d x=D_{11} \frac{\partial^{2} w}{\partial y^{2}}+D_{12} \frac{\partial \gamma_{y z}}{\partial y}=0
\end{aligned}
$$

である。

まず，境界条件を満たす面外のたわみ形 $w(x, y)$ を 次式で与える。

$$
w=\sum_{n=1}^{\infty} C_{n} \sin \left(\frac{n \pi x}{a^{\prime}}\right) \sin \left(\frac{\pi y}{b}\right)
$$

ここで, $n$ は, 半波の波数, $C_{n}$ は未定係数を表す。 また， $x=0, a$ 上の辺においては $\partial^{2} w / \partial x^{2}=0$ であり， $y=0, b$ 上の辺において $\partial^{2} w / \partial y^{2}=0$ となるので，せん 断ひずみ度に関する境界条件は，(6-1)，(6-2）式より 次のように与えられる。

$$
\left.\begin{array}{lll}
x=0, a \text { 上の辺において } & \gamma_{y z}=0, & \frac{\partial \gamma_{x z}}{\partial x}=0 \\
y=0, b \text { 上の辺において } & \gamma_{x z}=0, & \frac{\partial \gamma_{y z}}{\partial y}=0
\end{array}\right\}
$$

さらに, $x$ 軸に平行に切断した時に現れる面外曲げ変形 
モード (Fig.4(a) の $E-E$ 断面) が $\partial w / \partial x=0$ となる 山または谷の位置では，厚さ方向のどの位置において も（たとえばFig. 4(b) の $A$ や $B$ 点） $x$ 方向変位 $u$ は 等しく, $Z$ に依存しない。したがって（1）式より $\alpha(x, y)=0$ となり, さらに(2-1) の等 1 式を用いて, 次の条件を得る。

$$
\frac{\partial w}{\partial x}=0 \text { において } \quad \gamma_{x z}=0
$$

同样にして

$$
\frac{\partial w}{\partial y}=0 \text { において } \quad \gamma_{y z}=0
$$

これらの条件を満たす $\gamma_{x z}, \gamma_{y z}$ の分布関数を次のように 与える。

$$
\left.\begin{array}{l}
\gamma_{x z}=\sum_{n=1}^{\infty} D_{x n} \cos \left(\frac{n \pi x}{a}\right) \sin \left(\frac{\pi y}{b}\right) \\
\gamma_{y z}=\sum_{n=1}^{\infty} D_{y n} \sin \left(\frac{n \pi x}{a}\right) \cos \left(\frac{\pi y}{b}\right)
\end{array}\right\}
$$

ここに， $D_{x n}, D_{y n}$ は，未定係数である。

さらに，樹脂サンドイッチ鋼板に使用される樹脂の弾性 係数の值は, 一般に鋼の弾性係数の $10^{-3}$ 以下であるこ とに留意すると,次のような近似を行うことができる(記 号は, (4) 式参照)。

$$
\begin{aligned}
& D_{11 D}=2\left(1-\nu_{s}\right) D_{11}, \quad D_{12 D}=\left(1-\nu_{s}\right) D_{12}, \\
& D_{13 D}=\left(1-\nu_{s}\right) D_{13} / 2 \cdots \cdots \cdots \cdots \cdots \cdots \cdots \cdots \cdots \cdots \cdots \cdots \cdots \cdots \cdots
\end{aligned}
$$

(7-1)，(7-2)，（8）式を（4)，（5）式に代入し, 積分を行った後,

$$
\frac{\partial \Pi}{\partial C_{n}}=0, \quad \frac{\partial \Pi}{\partial D_{x n}}=0, \frac{\partial \Pi}{\partial D_{y n}}=0 \quad(n=1,2,3, \cdots \cdots)
$$

の条件から，座屈強度式を求めることができる。本論文 では,これら一連の解析をコンピュー夕を用い, 数式処 理言語 Reduceによって行っている。その結果，上式か ら導かれる条件式は， $n=1,2,3, \cdots に$ 対して，それぞ れ

$$
C_{n}=D_{x n}=D_{y n}=0 \cdots \cdots \cdots \cdots \cdots \cdots \cdots \cdots \cdots \cdots \cdots \cdots \cdots \cdots \cdots \cdots \cdots \cdots \cdots
$$

または， $\sigma_{c r}=N_{x} / A （ A$ は，樹脂を含む断面積）とし $\tau$

$$
\left.\begin{array}{c}
\sigma_{c r}=\frac{k \pi^{2} E_{s}}{12\left(1-\nu_{s}^{2}\right)}\left(\frac{T}{b}\right)^{2} \\
k=k_{0}\left\{1-\frac{k_{12}^{2}}{k_{13}+k_{21} b^{2} /\left(\pi^{2} \sqrt{k_{0}}\right)}\right\} \frac{D_{11}}{D_{0}}
\end{array}\right\}
$$

となる。これより 1 組の未定係数 $\left(C_{n}, D_{x n}, D_{y n}\right)$ に対 して (9-2) 式が成立し，他の未定係数の組は，(9-1) 式を満たす場合が条件式の解となる。したがって，樹脂 サンドイッチ鋼板の座屈応力度は, (9-2) 式で与えられ る。

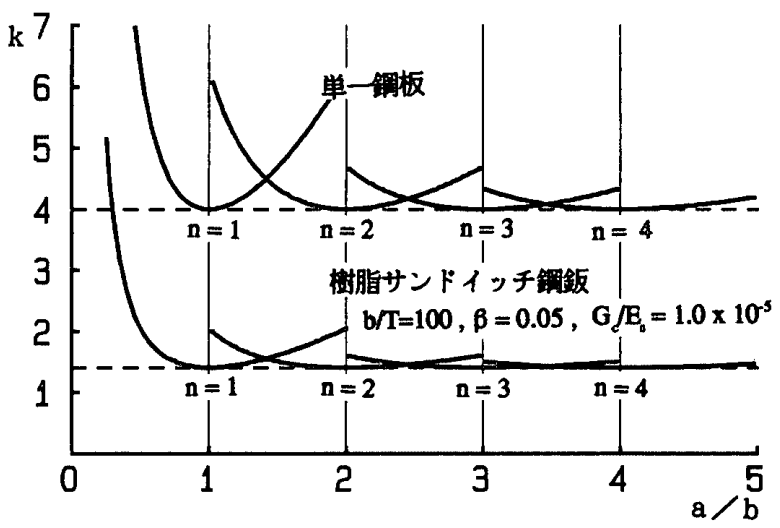

Fig. 5 樹脂サンドイッチ鋼板の座屈係数 $k$ とアスペクト比 $a / b$ の関係

これに基づいて，アスペクト比 $a / b$, 座屈波形の数 $n$ と座屈係数 $k$ の関係を単一鋼板の場合と比較して示 すと Fig. 5 となる。樹脂サンドイッチ鋼板の座屈係数 值は，アスペクト比が同じ単一鋼板に比べて小さいが, アスペクト比, 座屈波形の数と座屈係数の定性的性質は 変わらない。また，座屈係数の最小值は，単一鋼板の場 合と同様アスペクト比が, 整数值の時に与えられる。し たがって, 面内に純圧縮力を受ける周辺単純支持の樹脂 サンドイッチ鋼板の弾性座屈応力度の最小値は，（9） 式に $m=1$ を代入し, $\beta^{3} \cong 0$ として $D_{11} / D_{0}=1$ とすれば,

$$
\left.\begin{array}{l}
\frac{\sigma_{c r}}{\sigma_{y}}=\eta\left(\frac{\sigma_{c r 0}}{\sigma_{y}}\right)=\frac{\eta}{R^{2}} \\
\eta=1-\frac{3(1+\beta)\left(1-\beta^{2}\right)}{4\left(1+\Gamma R^{2}\right)}
\end{array}\right\}
$$

ここで, $\sigma_{c r 0}$ : 単一鋼板の座屈応力度 $\left(k_{0}=4\right)$

$$
\Gamma=\frac{2\left(G_{c} / E_{s}^{\prime}\right)}{3 \beta(1-\beta)\left(\sigma_{y} / E_{s}^{\prime}\right)}, \quad E_{s}^{\prime}=\frac{E_{s}}{1-\nu_{s}^{2}}
$$

$\sigma_{y}:$ 樹脂サンドイッチ鋼板の降伏応力度

$$
R=\frac{b}{T} \sqrt{\frac{12\left(1-\nu_{s}\right) \sigma_{y}}{\pi^{2} E_{s} k_{0}}}=0.526 \frac{b}{T} \sqrt{\frac{\sigma_{s}^{\star}}{E_{s}}}
$$

$$
\text { (ただし， } \left.\nu_{s}=0.3 ， k_{0}=4\right)
$$

となる。なお，樹脂サンドイッチ鋼板の降伏応力度とは， 樹脂サンドイッチ鋼板の引張力による降伏荷重を樹脂を 含む全断面積で除して求められた降伏応力度を言う。

(10) 式において $\eta=1$ とすれば，単一鋼板に対する弾 性座屈応力度の評価式

$$
\frac{\sigma_{c r}}{\sigma_{y}}=\frac{1}{R^{2}}
$$

に一致する。 $\eta$ は樹脂サンドイッチ鋼板の座屈強度に対 して樹脂層が与える影響の度合いを示すものとなってい る。また，樹脂サンドイッチ鋼板が座屈を起こすときの 面外曲げ剛性の見かけ上の低下率と見なすこともでき る。本論文では， $\eta$ を座屈影響係数と呼ぶことにする。 この $\eta$ の值は，樹脂厚比 $\beta$, 鋼板のヤング係数に対する 樹脂のせん断弾性係数比 $G_{c} / E_{s}$, 幅厚比 $b / T$ の影響を 
受ける。

（10）式を変形して,

$$
\frac{\sigma_{c r}}{\sigma_{y}}=\frac{1}{(R / \sqrt{\eta})^{2}}=\frac{1}{R_{e}^{2}}
$$

とすれば， $R_{e}$ は，樹脂サンドイッチ鋼板と同一の座屈 強度を与える単一鋼板の幅厚比パラメーター $R$ の值を 表している。この $R_{e}$ を樹脂サンドイッチ鋼板の有効座 屈パラメーターと呼ぶこととする。 樹脂サンドイッチ鋼板の有効幅厚比パラメーターは，樹 脂サンドイッチ鋼板の全厚と等しい板厚を有する単一鋼 板の幅厚比パラメーターよウもも大きななるなお，(10) 式で与えられる $\eta$ は，面内に圧縮力を受ける四辺単純 支持された樹脂サンドイッチ鋼板に対しての評価式であ り，板の支持条件，荷重条件によって異なることとなる。 2.2 後座屈強度

面内圧縮力を受ける 4 辺を支持された薄板では，座屈 荷重よりも大きな荷重を支えることができることは周知 のとおりである。この時の面内圧縮力に対する最大耐力 を後座屈強度之呼ぶ。

後座屈強度を解析的に求める方法として, 塑性関節に よる板の崩壊メカニズムに基づく方法8)，弾性大たわみ 解析之塑性解析を組み合わせる方法"，弾性大たわみ解 析と圧縮荷重を受けている辺で生じている最大応力度に 対する降伏条件とから求める方法 ${ }^{10}$ 等が提案されてい る。宇佐見ら ${ }^{10)}$ は，第 3 の方法により面内に曲げと圧縮 を受ける矩形板の後座屈強度を求め, 王縮力のみを受け る場合については幅厚比パラメーター $R$ の小さい範囲 を除くとWinter の式と良く一致することを報告してい る。このことから,幅厚比が小さい場合を除けば,「板は, 後座屈強度に達する直前まで弾性状態として扱える」と 判断することができる。したがって，座屈後の面外変形 のモードが大きく変化し，樹脂層のせん断変形の面外曲 げ㴊性に与える影響に違いが生ずることがなければ，樹 脂サンドイッチ鋼板の後座屈強度評価式は，単一鋼板の 後座屈強度評価式中の曲げ剛性値を樹脂サンドイッチ鋼 板のそれに置き換完ることによって得られることにな る。

すなわち, 単一鋼板の後座屈強度評価式が

$$
\begin{aligned}
& \sigma_{u}=f(R) \\
& R=\frac{b}{T} \sqrt{\frac{12\left(1-\nu_{s}^{2}\right) \sigma_{y}}{\pi^{2} E_{s} k_{0}}} .
\end{aligned}
$$

で与えられるものとすれば,

$$
\frac{1}{R^{2}}=\frac{k_{0} D_{0}}{A b \sigma_{y}} \quad\left(\because D_{0}=\frac{E_{s} T^{3}}{12\left(1-\nu_{s}^{2}\right)}, A=b T\right)
$$

となり，曲げ剛性 $D_{0}$ をを $\eta D_{0}$ に置き換えれば，樹脂サン ドイッチ鋼板の後座屈強度評価式として,

$$
\sigma_{u}=f\left(R_{e}\right)
$$

ここに, $R_{e}=R / \sqrt{\eta}$

を得る。すなわち，樹脂サンドイッチ鋼板の後座屈強度 式は, 幅厚比パラメーター $R$ の代わりに, 有効幅厚比 パラメーター $R_{e}$ を用いた式となる。

ここで，面内に圧縮力のみを受ける四辺単純支持の単 一鐝板の後座屈強度評価式として，有効幅 $b_{e}$ を与える Winter $の$ 式 ${ }^{12)}$

$$
\frac{b_{e}}{b}=1.90\left(\frac{T}{b}\right) \cdot \sqrt{\frac{E_{s}}{\sigma_{\max }}} \cdot\left\{1-0.475\left(\frac{T}{b}\right) \sqrt{\frac{E_{s}}{\sigma_{\max }}}\right\}
$$

を用い, $\sigma_{\max }=\sigma_{y}$ 之置けば，(11）式より樹脂サンドイッ 于鋼板の後座屈強度式は，次式となる。

$$
\left.\begin{array}{c}
\frac{\sigma_{u}}{\sigma_{y}}=\frac{1}{R_{e}}\left\{1-0.25\left(\frac{1}{R_{e}}\right)\right\} \\
\text { ここで, } R_{e}=\frac{R}{\sqrt{\eta}}=0.526\left(\frac{b}{T}\right) \frac{\sqrt{\sigma_{y} / E_{s}}}{\sqrt{\eta} \cdot}
\end{array}\right\}
$$

また, 単一鋼板の後座屈強度評価式として, 限界幅厚比 を超えた部分の断面を無効とみなしての降伏強度

$$
\frac{\sigma_{u}}{\sigma_{y}}=\frac{0.861}{R}
$$

を用いれば，樹脂サンドイッチ鋼板の後座屈強度は，上 式の偪厚比パラメーター $R$ を有効幅厚比パラメーター に置換して

$$
\frac{\sigma_{u}}{\sigma_{y}}=\frac{0.861}{R_{e}}
$$

となる。

なお，有効幅厚比パラメーターの概念を用いずに，日本 建築学会規準の考え方 $\left(\sigma=0.6 \sigma_{y}\right.$ において弾性座屈曲 線之接する接線が $\sigma_{y}$ を与える幅厚比 $R_{D}$ を限界幅厚比

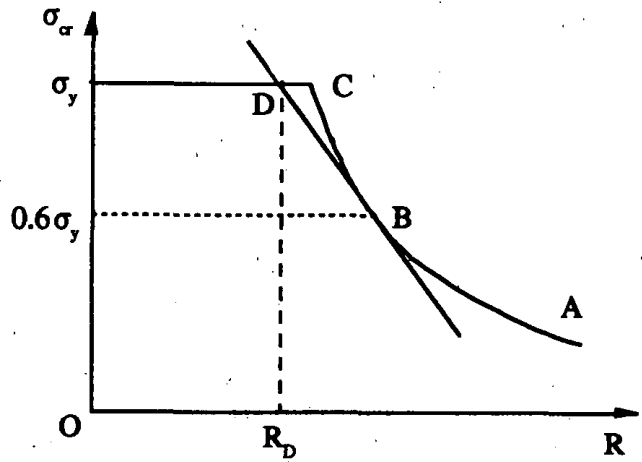

Fig. 6 日本建築学会の限界幅厚比の考え方

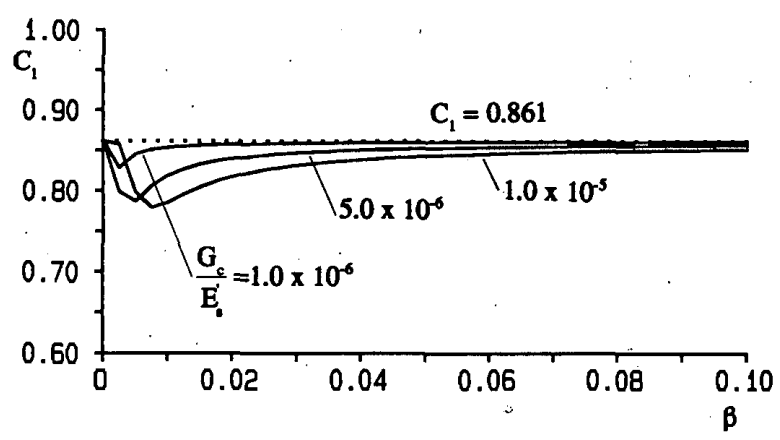

Fig. $7 C_{1}$ 之樹脂厚比 $\beta$ の関係 
とする一Fig. 6 参照) をを直接 (10) 式に適用して限界幅 㕌比を求め, 限界幅厚比を超えた部分の断面を無効とみ なして, 樹脂サンドイッチ鋼板の後座屈強度を求めると,

$$
\frac{\sigma_{u}}{\sigma_{y}}=\frac{C_{1}}{R}
$$

となる。C $C_{1}$ は, Fig. 7 のように樹脂厚比 $\beta$ および樹脂 のせん断弾性係数 $G_{c}$ の影響を受けるが, $\beta$ が比較的大 きな範囲 $(\beta>0.02)$ を対象として一定值（Fig.7 中の 点線の值）を $C_{1}$ に用いれば, 上式は（13）式に一致す ることとなる。

\section{3. 実 験}

2 節では, 面内に圧縮力のみを受ける四辺単純支持の 樹脂サンドイッチ鋼板に対する座屈強度評価式および終 局強度式を提示した。これら評価式の妥当性を検討する ために，樹脂サンドイッチ鋼板の面内に王縮力を作用さ せる載荷実験を行い，これらの結果と解析結果とを比較 検討する。

\section{1 概 要}

実験で信頼できる最小の座屈荷重が得られるようにす るためには，座屈モードの波数やアスペクト比に対する 影響が小さくなるアスペクト比の大きな供試体で実験を 行うのが良い。そこで, 実験装置等を考慮した上, 供試 体のアスペクト比を 3 とした（Fig.8(a) 参照)。また， 供試体の材種, 板厚 $t$, 板幅 $b$ (加力される辺の寸法) の組み合わせは Table 1 とした。なお, 樹脂サンドイッ 千鋼板の供試体名の頭には $V$, 単一鋼板の供試体名の 頭には $N$ を付け, 樹脂サンドイッチ鋼板の公称板厚は, <表層の鋼板 1 の板厚 > $/$ <表層の鋼板 2 の板厚＞で表 記している。公称樹脂厚は, $1.2 / / 1.2$ において $0.04 \mathrm{~mm}$, その他はすべて $0.05 \mathrm{~mm}$ である。使用した樹脂サンド イッチ鋼板および単一鋼板の機械的性質を Table 2 に示

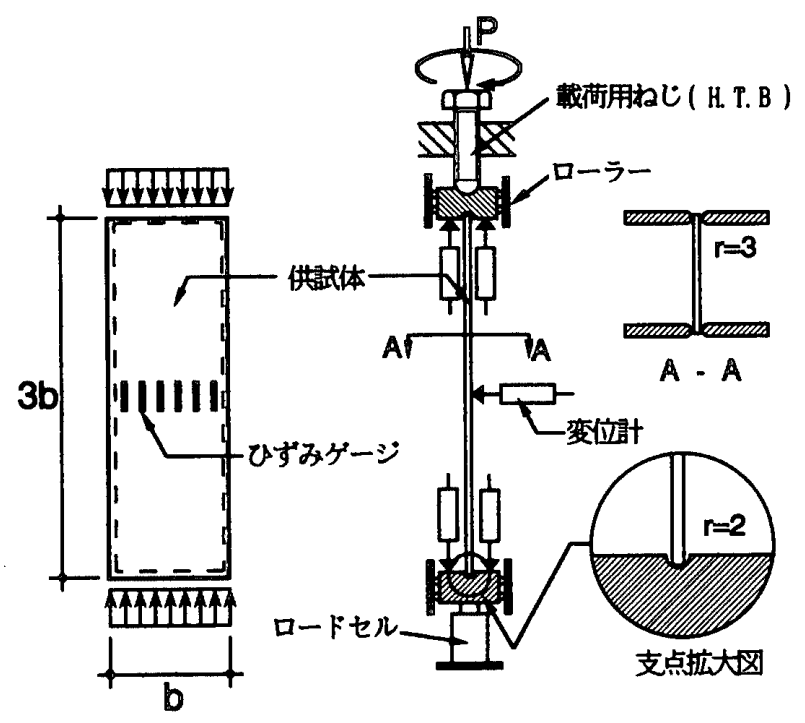

（a）供試体

（b）載荷装置の概要

Fig. 8 供試体之載荷装置の概要
す。ここに示す樹脂サンドイッチ鋼板に対する降伏応力 度および引張強さは, 樹脂を含む実测断面積を用いて算 定している。また, 樹脂のせん断弾性係数は, 樹脂サン ドイッチ鋼板に対して行った 3 点曲げ試験（試験片寸法 $30 \times 150 \mathrm{~mm}$, 支点間距離 $100 \mathrm{~mm}$ ) の結果から算定して いる (Apendix-1 参照)。供試体の 4 辺単純支持の条件 を実現させるため，Fig. 8(b) のように短辺では， $r=2$ $\mathrm{mm}$ の半円形の溝によって，また長辺では，小口が半円 形加工された 2 枚の平鋼で供試体を挟んで支持した。変 位制御による載荷は, 装置上部の載荷用ねじ（H. T.B. M24）を回転させ，押し出すことによって行った。計测 は, 鋼板の面外変位之載荷方向の変位測定 (Fig.8(b)), ならびに,Fig.8(a) の中のIに示す位置でひずみ度の 測定を行っている。

\section{2 実験結果}

Table 3 に結果の概要を示す。座屈は，1 例を除き， すべて半波の波数が 3 の座屈モードで生じたが，供試体 V 1025-1 では，半波の波数が 4 の座屈モードとなった。 (10) 式と実験結果とを比較するには，固有值としての 座屈荷重を実験值から推定する必要がある。ここでは, $P-\delta^{2}$ 法 $^{(6) 14)}$ と Southwell の方法 ${ }^{14), 15)}$ の $2 つ の$ 方法を用 いて推定した。1 例を Fig. 9 と Fig. 10 に示す。Fig. 9 では, 横軸に供試体中央の面外変形量 $w$ を全厚 $T$ で除 した值 $w / T$ の 2 乗を，また縦軸には，圧縮荷重を樹脂 を含む断面積で除した值 $\sigma$ をとり, $p-\delta^{2}$ 法により座屈 応力度を推定している。また, Fig. 10 では, Fig. 9 と 同じ供試体について， $w / T$ と $w / T$ を $\sigma$ で除した值と の関係を求め, Southwell の方法に基づいて $w / T=0$ 近傍の曲線の傾き（図中の破線の傾き）の逆数から推定 している。なお，破線の $x$ 軸切片の值は，推定される 面外初期たわみ量を表している。このようにしてそれぞ れの供試体に対する $p-\delta^{2}$ 法による座屈応力度および

Table 1 供試体の板幅 $b$ 之幅厚比 $b / T$

\begin{tabular}{|c|c|c|c|c|c|c|}
\hline \multirow{2}{*}{$b / T$} & \multicolumn{4}{|c|}{ 樹脂サンドイッチ鐡鈑 } & \multicolumn{2}{|c|}{ 単一鋮鈑 } \\
\hline & $0.27 / 10.27$ & $0.4 / / 0.4$ & $1.0 / 11.0$ & $1.2 / 11.2$ & 1.2 & 2.0 \\
\hline $\begin{array}{l}25 \\
50 \\
75\end{array}$ & 60 & 60 & $\begin{array}{r}50 \\
100\end{array}$ & $\begin{array}{r}60 \\
120\end{array}$ & & $\begin{array}{r}50 \\
100\end{array}$ \\
\hline $\begin{array}{l}100 \\
125\end{array}$ & & 80 & $\begin{array}{l}200 \\
250\end{array}$ & 240 & & 200 \\
\hline $\begin{array}{r}150 \\
200 \\
\end{array}$ & $\begin{array}{r}90 \\
120 \\
\end{array}$ & $\begin{array}{l}120 \\
160 \\
\end{array}$ & & & 240 & \\
\hline
\end{tabular}

Table 2 樹脂サンドイッチ鋼鈑と単一鋼鈑の機械的性質

\begin{tabular}{|c|c|c|c|c|c|}
\hline 傸試体 & Y.P $\left(t / \mathrm{cm}^{2}\right)$ & $T . P\left(t / \mathrm{cm}^{2}\right)$ & EL (\%) & G/E & $\beta($ 公称) \\
\hline $0.27 / 10.27$ & 3.38 & 3.52 & 28.5 & $9.18 \times 10^{6}$ & 0.0847 \\
\hline $1.0 / 1 / 1.0$ & 2.54 & 3.51 & 43.9 & $4.52 \times 10^{6}$ & 0.0244 \\
\hline $1.2 / 112$ & $1.59^{*}$ & 3.09 & 47.1 & $7.23 \times 10^{6}$ & 0.0164 \\
\hline $\begin{array}{l}1.2 \mathrm{~mm} \\
2.0 \mathrm{~mm}\end{array}$ & $\begin{array}{l}1.58^{*} \\
2.66\end{array}$ & $\begin{array}{l}2.94 \\
3.62\end{array}$ & $\begin{array}{l}54.6 \\
46.3\end{array}$ & & \\
\hline
\end{tabular}

*0.2\%オフセット觔力

E。䌮のヤング保数
G。樹脂のせん新弾性係数 $\beta$ 㴻脂得比 
Table 3 実験結果の概要

\begin{tabular}{|c|c|c|c|c|c|c|c|c|c|c|c|}
\hline 試験体名 & 鋰材 & $\mathrm{T}$ & $\mathrm{b} / \mathrm{T}$ & $\sigma_{y}$ & $\overline{\mathbf{R}}$ & $\lambda$ & $\lambda_{0}$ & $\sigma_{\mathrm{ot}} / \sigma_{\mathrm{y}}$ & $\sigma_{\alpha 2} / \sigma_{y}$ & $\sigma_{\mathrm{a}} / \sigma_{\mathrm{y}}$ & Temp. \\
\hline N2005-1 & $2.0 \mathrm{~mm}$ & 2.03 & 24.4 & 2.66 & $\overline{0.46}$ & 0.87 & 0.87 & $\rightarrow$ & & 0.802 & \\
\hline $\mathrm{N} 2010-1$ & & & 48.8 & & 0.91 & 173 & 1.73 & 4 & {[} & 0.728 & 18.0 \\
\hline $\mathrm{N} 2020-1$ & & & 97.6 & & 1.88 & 3.57 & 3.57 & 0.307 & 0.311 & 0.765 & 20.8 \\
\hline & & 1.93 & 103.6 & & 1.99 & 3.78 & 3.78 & 0.273 & 0.280 & 0.463 & \\
\hline N1224-1 & $1.2 \mathrm{~mm}$ & 1.16 & 206.9 & 1.58 & 2.99 & 5.68 & 5.68 & \begin{tabular}{|l|}
0.108 \\
0.101
\end{tabular} \mid & $\begin{array}{l}0.101 \\
0.089\end{array}$ & $\begin{array}{l}0.293 \\
0.271\end{array}$ & 20.2 \\
\hline V1206-1 & $1.2 \| 1.2$ & 2.42 & 24.8 & 1.59 & 0.36 & 0.68 & 1.31 & & & 0.907 & \\
\hline V1212-1 & & & 49.6 & & 0.72 & 1.37 & 2.28 & 0.593 & - & 0.760 & 17.2 \\
\hline V1224-1 & & & 992 & & 1.44 & 2.74 & 3.65 & $\begin{array}{l}0.303 \\
0327\end{array}$ & 0271 & 0.42 & 202 \\
\hline & & & & & & & & 0.227 & 0.269 & 0.432 & \\
\hline V1005-1 & $1.0 / / 1.0$ & 2.03 & 24.7 & 2.54 & 0.45 & 0.86 & 1.73 & 4 & & 0.680 & \\
\hline V1010-1 & & & 49.3 & & 0.90 & 1.71 & 3.19 & 0.308 & 0.308 & $\begin{array}{l}0.084 \\
0.444\end{array}$ & 17.8 \\
\hline V1020-1 & & & 98.5 & & 1.80 & 3.42 & 5.32 & $\begin{array}{l}0.281 \\
0.108\end{array}$ & $\begin{array}{l}0.381 \\
0.125\end{array}$ & $\begin{array}{l}0.477 \\
0266\end{array}$ & 219 \\
\hline & & & & & & & & 0.126 & 0.129 & 0.268 & \\
\hline V1025-1 & . & & 123.2 & & 2.28 & 4.33 & 6.22 & $\begin{array}{l}0.092 \\
0.081\end{array}$ & 0.099 & $\begin{array}{l}0.272 \\
0.268\end{array}$ & \\
\hline V0406-1 & $0.4 / / 0.4$ & 0.93 & 64.5 & 3.46 & 1.38 & 2.62 & 5.25 & 0.149 & 0.152 & 0.278 & \\
\hline V0408-1 & & & 86.0 & & 1.83 & 3.48 & 6.58 & 0.092 & 0.102 & 0.222 & \\
\hline$v 0412-1$ & & & 129.0 & & 2.76 & 5.24 & 8.78 & $\begin{array}{l}0.113 \\
0.047\end{array}$ & 0.100 & $\begin{array}{l}0.194 \\
0.128\end{array}$ & 20.5 \\
\hline V0416-1 & & & 172.0 & & 3.67 & 6.98 & 10.53 & $\begin{array}{l}0.047 \\
0.022\end{array}$ & $\begin{array}{l}0.057 \\
0.024\end{array}$ & $\begin{array}{l}0.139 \\
0.106\end{array}$ & 21.0 \\
\hline$\frac{-2}{V 030}$ & $0.27 / 10.27$ & & & & & & & $\frac{0.023}{0.137}$ & 0.025 & 0.104 & \\
\hline$\sqrt{0} 306-1$ & 0.270 .21 & 0.65 & 92.3 & 3.38 & 1.95 & 3.71 & 6.71 & $\begin{array}{l}0.137 \\
0.125\end{array}$ & $0 . \overline{153}$ & $\begin{array}{l}0.260 \\
0.267\end{array}$ & \\
\hline $\mathrm{V} 0309-1$ & & & 138.5 & & 2.92 & 5.55 & 8.66 & 0.066 & 0.071 & $\begin{array}{l}0.155 \\
0.165\end{array}$ & \\
\hline V0312-1 & & & 184.6 & & 3.90 & 7.41 & 10.36 & 0.030 & 0.032 & 0.155 & 18.5 \\
\hline & & & & & & & & & & $-b$ & $\mathbf{E}$ \\
\hline
\end{tabular}

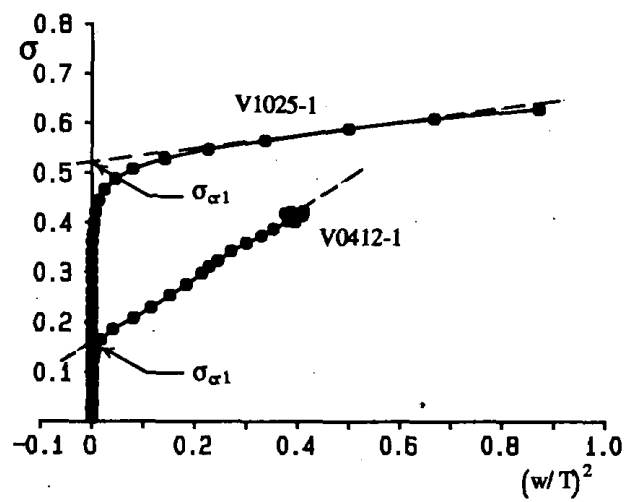

Fig. $9 P-\delta^{2}$ 法による坐屈応力度

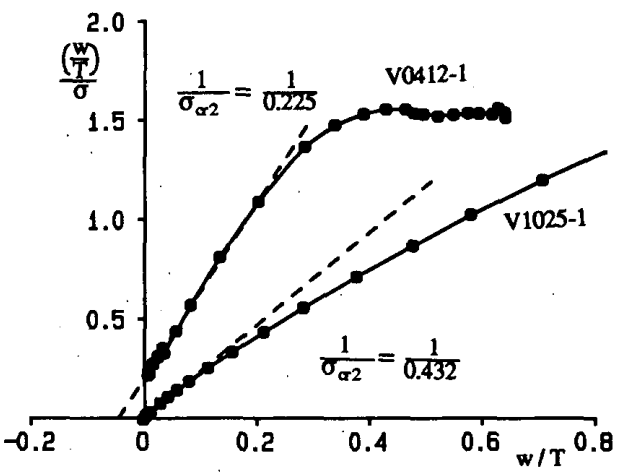

Fig.10 Southwell 法による坐屈応力度
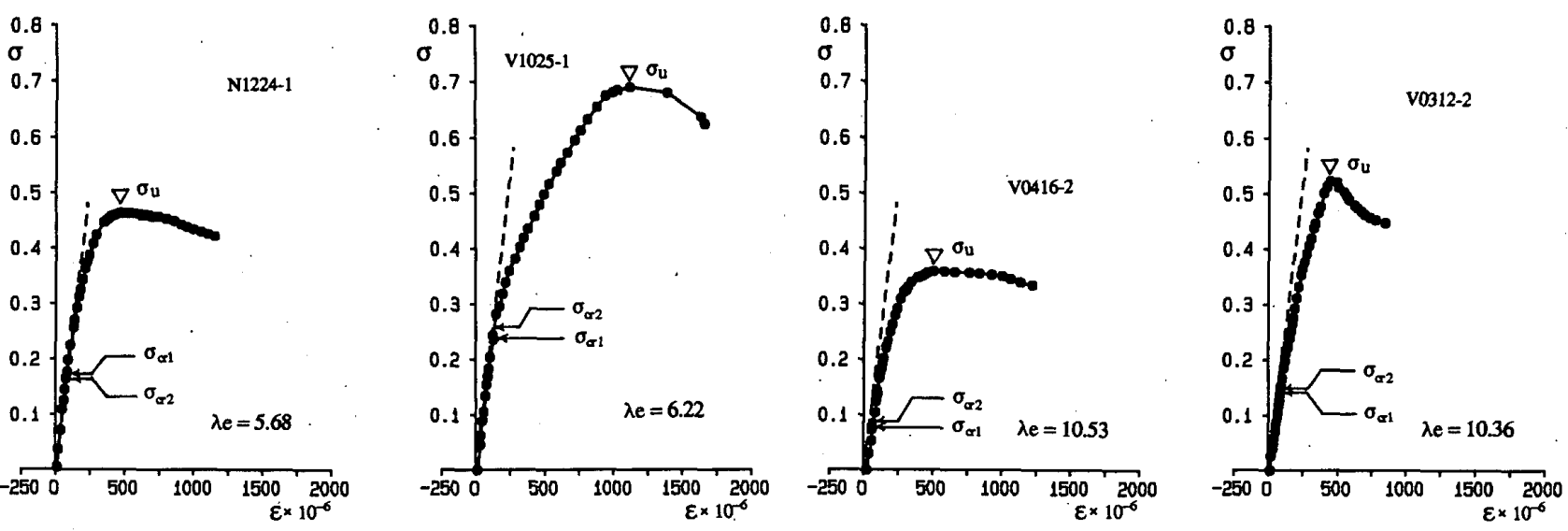

Fig. 11 載荷方向の荷重-変位関係

Southwell の方法による座屈応力度を求め, 表中に $\sigma_{c r 1}, \sigma_{c r 2}$ として示している。 $\sigma_{c r 2}$ に比べ $\sigma_{c r 1}$ の方がや や低めとなっているが大きな差は認められない。なお， 表中の幅厚比パラメーター $R$ および $\lambda$ は, 次式によっ て算定された值であり， $R=0.526 \lambda$ の関係がある。

$$
R=0.526\left(\frac{b}{T}\right) \sqrt{\frac{\sigma_{y}}{E_{s}}}, \quad \lambda=\left(\frac{b}{T}\right) \sqrt{\frac{\sigma_{y}}{E_{s}}}
$$

ここに，記号は，（10）式参照

樹脂サンドイッチ鋼板による供試体の $\lambda_{e}$ は， 1.31 から 10.53 の範囲にある。

Fig. 11 に, 載荷方向の荷重-変位関係を, それぞれ樹 脂を含む断面積および供試体長さで除した平均応力度, 平均ひずみ度で示す。図中には， $\sigma_{u}, \sigma_{c r 1}, \sigma_{c r 2}$ と計算に

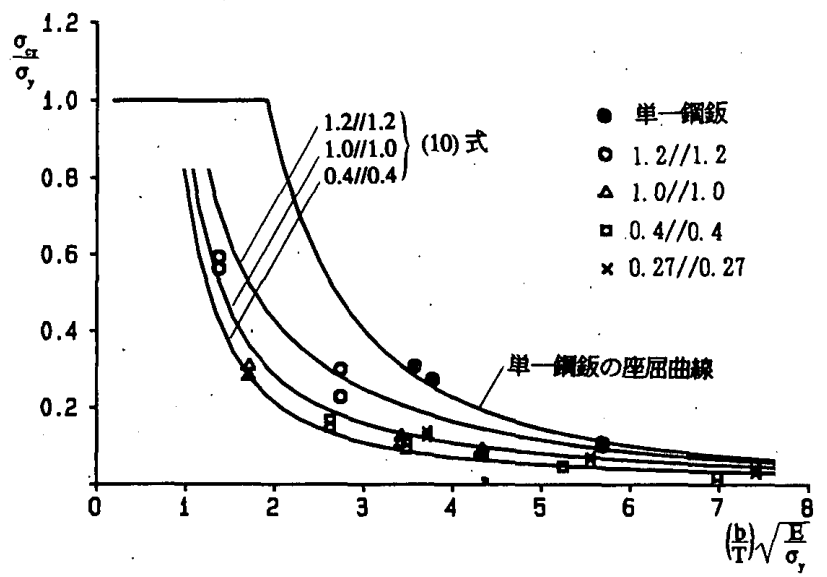

Fig. 12 座屈応力度と幅厚比パラメーターの関係 
よる初期剛性を破線で示してある。載荷方向の荷重一変 形関係に大きな性状の差は認められない。

Fig. 12 に幅厚比パラメーター $\lambda$ と $\sigma_{c r 1} / \sigma_{y}$ の関係を示 す。図には，弾性座屈していると思われる $\sigma_{c r 1} / \sigma_{y}<0.6$ の結果のみを示した。全厚が小さく，樹脂厚比が大きい 樹脂サンドイッチ鋼板ほど, 座屈応力度の低下が大きい ことが認められる。図中の実線は，単一鋼板の弾性座屈 曲線ならびに（10）式による樹脂サンドイッチ鋼板の座 屈曲線である。単一鋼板では，弾性座屈曲線之ほぼ一致 しており，P- $\delta^{2}$ 法により推定した固有值としての座屈 荷重が妥当であることを示している。樹脂サンドイッチ 鋼板においても，実験值と（10）式とはほぼ一致してい ると思われるが，ばらつきがやや大きい。そこで，横軸 を有効幅厚比パラメーター $\lambda_{e}(=\lambda / \sqrt{\eta})$ に関する対数 軸, 縦軸を $\sigma_{\mathrm{crl}} / \sigma_{y}$ に関する対数軸として実験值をプ ロットしたFig. 13 によっ，(10) 式の妥当性を検討 する。（10）式による值は，図中に実線で示している。 樹脂サンドイッチ鋼板 $0.4 / / 0.4$ および $0.27 / / 0.27$ に対

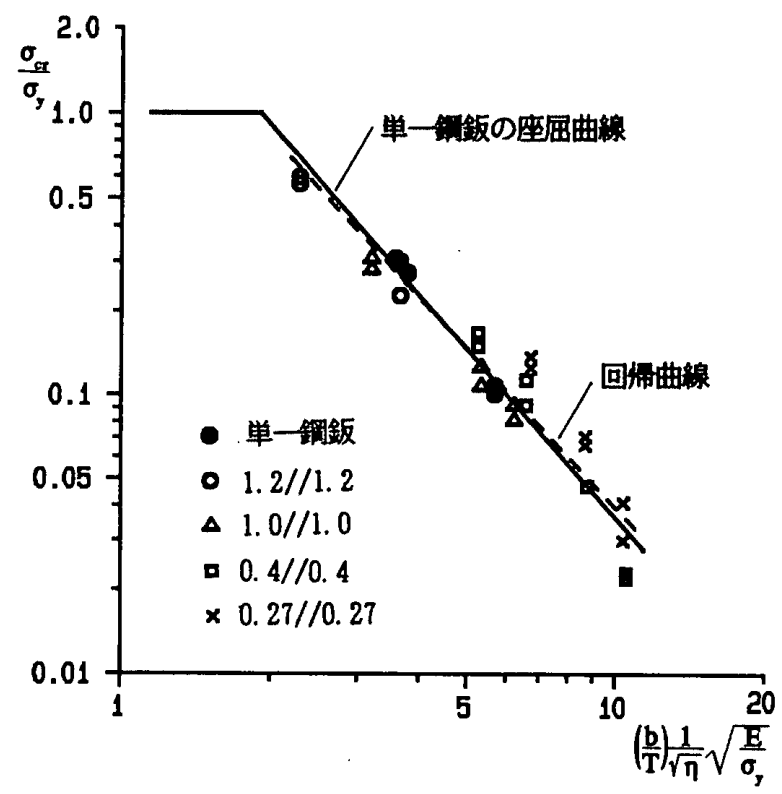

Fig. 13 㭫屈応力度と有効幅厚比パラメーターの関係
する実験值のばらつきは,他の供試体と比べて大きいが, それは $1.2 / / 1.2,1.0 / / 1.0$ に比べ，板厚が薄いため初 期不整, 测定誤差等の影響を受けやすいためと思われる。 この点を考慮すれば，実験値と（10）式とは概ね良く一 致していると判断できる。なお，図中の破線は，実験值 から最小 2 乗法により求めた回帰曲線である。

最大平均応力度 $\sigma_{u}$ (後座屈強度) と幅厚比パラメー ターの関係を Fig. 14 に示す。図中の破線は, Winter の 式に基づく（12）式，また，実線は，日本建築学会規準 の限界幅厚比に基づく後座屈強度 (13) 式である。破線, 実線とも幅厚比パラメーターの大きい範囲ではあまり差 はなく, 単一鋼板の後座屈強度は, 実線の評価とほぼ一 致している。樹脂サンドイッチ䤡板の後座屈強度は, 単 一鋼板に比べて低く, 樹脂厚比が大きいほど後座屈強度 の低下は大きい。これは, 座屈強度の場合と同じ傾向を 示している。供試体 $0.4 / / 0.4$ に対する結果と (13) 式 による評価とを比べると実験值の方が低い。これらの值 は, $0.4 \mathrm{~mm}$ の単一鋼板を 2 枚重ねた場合の終局強度 (図

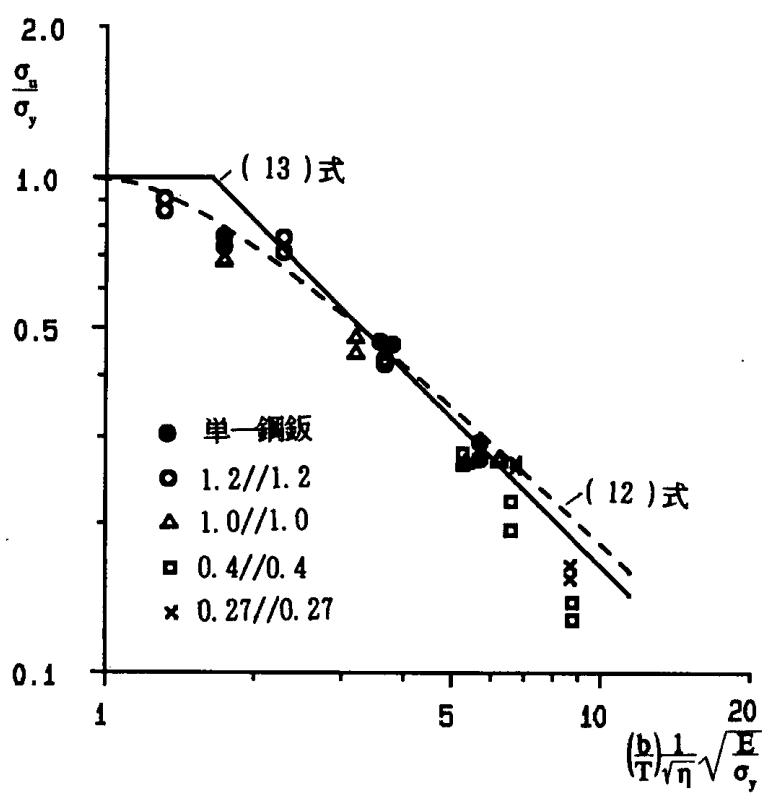

Fig. 15 最大平均忘力度と有効幅厚比パラメーターの関係

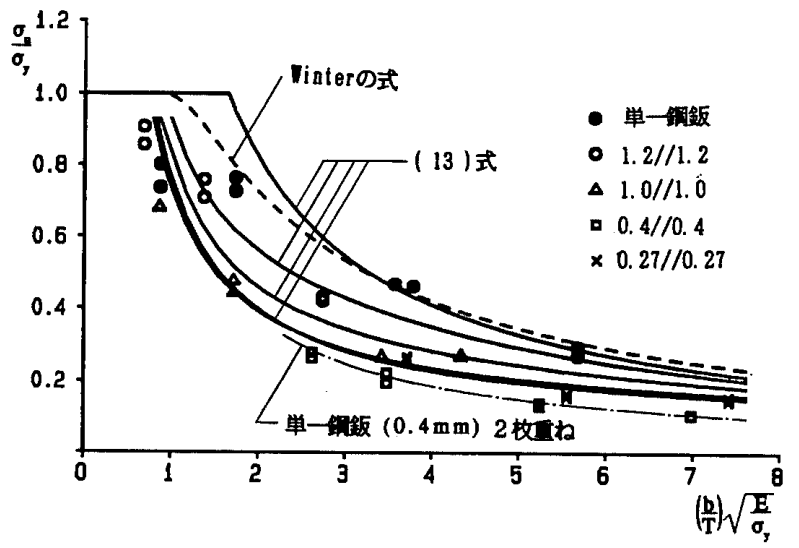

Fig. 14 最大平均応力度と幅厚比パラメーターの関係
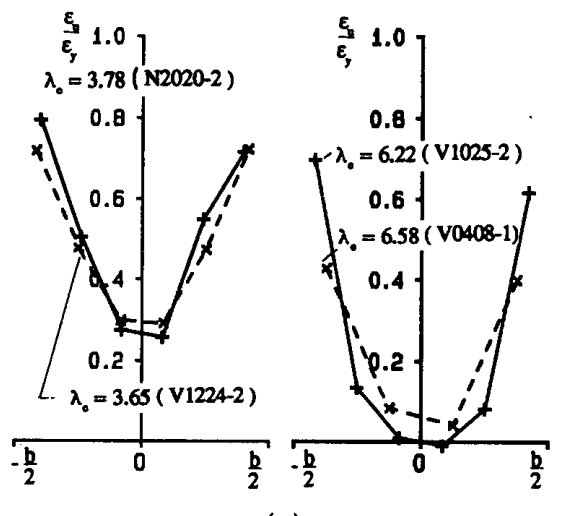

(a)

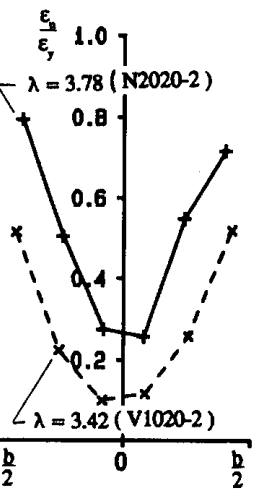

(b)

Fig.16 最大荷重時におけるひずみ度分布の比較 
中の 1 点鎖線) の值か, それより低い值であり, 初期不 整による影響と考えるのが妥当と思われる。Fig. 15 は, Fig. 13 と同様に後座屈強度を有効幅厚比パラメーター との関係で示した図である。実験値は，有効幅厚比の比 較的小さい範囲では，破線で示した（12）式に，また有 効幅厚比パラメーターの大きい範囲では, $0.4 / / 0.4$ の 夷験結果を除けば，実線で示した（13）式に良い一致を 示している。

Fig. 16 は, 最大荷重時の幅方向のひずみ度分布を比 較したものである。(a) 図では，ほぼ有効幅厚比パラメ一 ター $\lambda_{e}$ が等しい供試体について, (b) 図では, 幅厚比 パラメーター 入が等しい供試体について比較している。 有効幅厚比パラメーターが等しければ，ひずみ度分布も ほぼ等しくなっており，この図からも有効幅厚比パラ メーターの有効性が認められる。

\section{4. 座屈影響係数 $\eta$ の特性}

3 節の実験により，有効幅厚比パラメーターを用いて 与えられる樹脂サンドイッチ鋼板の弾性座屈強度式(10) 式および後座屈強度式 (12)，（13）式の妥当性が示され た。ここでは, 有効幅厚比パラメーターを定義づける座 屈影響係数 $\eta$ の特性を考察する。

Fig. 17 は, 弾性座屈係数 $\eta$ に及ぼす樹脂層のせん断弹 性係数 $G_{c}$ の影響を示す図である。縦軸は, 座屈影響係 数 $\eta$, 横軸は, 鋼の縦弾性係数 $E_{s}^{\prime}\left(=E_{s} /\left(1-v_{s}^{2}\right)\right)$ に 対する樹脂層のせん断弾性係数 $G_{c}$ の比 $G_{c} / E_{s}^{\prime}$ である。

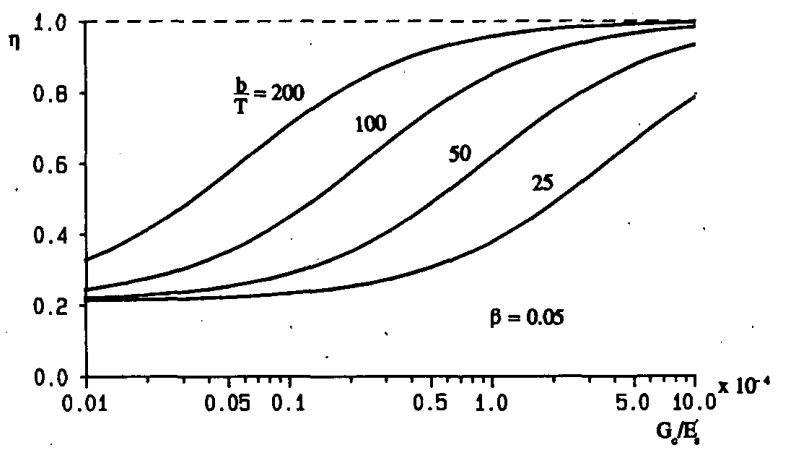

Fig. 17 澍脂のせん断弾性係数 $G_{c}$ が座屈影響係数 $\eta$ に与える 影響

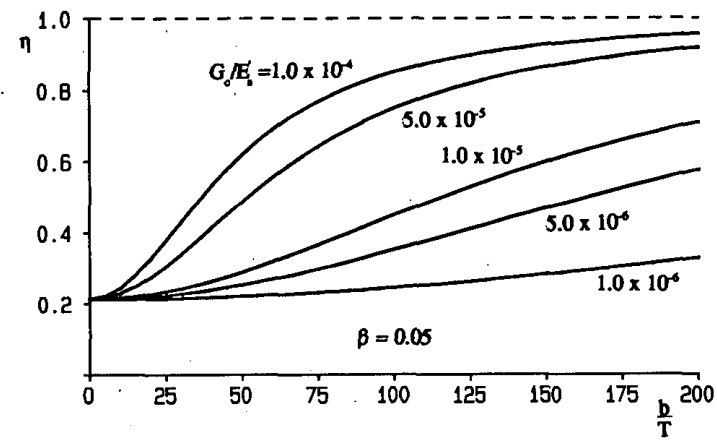

Fig. 18 幅厚比 $b / T$ が座屈影響係数 $\eta$ に与える影響

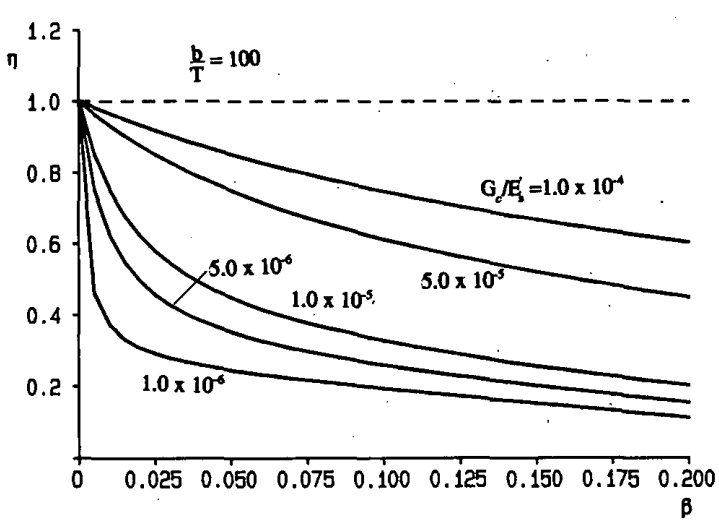

Fig. 19 樹脂厚比 $\beta$ が座屈影響係数 $\eta$ に与える影響

この図より樹脂サンドイッチ鋼板の座屈応力度は，樹脂 のせん断弾性係数 $G_{c}$ に大きく依存していることが認め られる。これは，樹脂層がせん断変形を起こすと，樹脂 を挟むそれぞれの鋼板（鋼板 1, 鋼板 2）内に中立軸が 移動し，その結果として面外曲げ剛性が低下するためで ある。 $G_{\mathrm{c}} / E_{s}^{\prime}$ が小さいほど中立軸の移動量は大きくな る。樹脂サンドイッチ鋼板の 3 点曲げでは，支点間距離 が小さいほど曲げ剛性が低下するが, 板座屈においては,

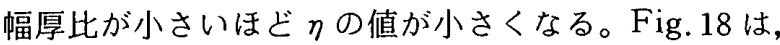
幅厚比がクに及ぼす影響を示した図である。幅厚比が 大きくなるほよ゙， $\eta$ の值は増加し， $\eta=1$ に漸近する。 $G_{c} / E_{s}^{\prime}$ の $\eta$ に及ぼす影響の差は, 幅厚比が大きいほど 大きく，幅厚比が小さい場合には $G_{c}$ の影響は小さい。

Fig. 19 は， $\eta$ と樹脂厚比の関係を示している。樹脂厚 比が大きいほよ゙ $\eta$ は低下し，特に樹脂のせん断弾性係 数が小さいほど顕著となる。 $G_{c} \neq 0$ であれば， $\beta=0$ に おいて $\eta=1$ となっているが，樹脂層が無く 2 枚の鋼板 がそのまま重ねられている場合を想定すれば， $\beta=0$ か つせん断弾性係数 $G_{c}=0$ となるので， $\eta$ の值は 1 となら ず $1 / 4$ となる。

$\eta$ は，単一鋼板の座屈強度に対する等厚の樹脂サンド イッチ鋼板の座屈強度の比を与えるものであるが，終局

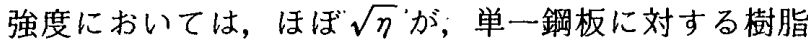
サンドイッチ鋼板の終局強度比を表す。したがって，幅 厚比, 樹脂厚比, せん断弾性係数等が及ぼす樹脂サンド イッチ鋼板の終局強度への影響は，座屈強度に対する影 響と定性的には同じと考えられる。

\section{5. 結 論}

本研究では, 面内に圧縮力のみを受ける樹脂サンド イッチ鋼板に対し，樹脂層のせん断変形を考慮した板座 屈解析を行い，弾性座屈強度式を導くとともに，有効幅 厚比の概念を導入し，後座屈強度を与える式を提唱した。 さらに, 有効幅厚比パラメーターが 1.3 から 10.5 の樹 脂サンドイッチ鋼板の供試体による実験を行い，これら 提唱した強度式の妥当性を確認した。その結果，次の点 
が明らかになった。

（1）面内に純圧縮力を受ける 4 辺単純支持され，また 樹脂厚比 $\beta$ が $\beta^{3} \cong 0$ とみなせる樹脂サンドイッチ鋼板 の弾性坐屈強度は, (10) 式で評価できる。

（2）樹脂サンドイッ千鋼板の後座屈強度は, 有効幅厚 比パラメーターを用いて導かれる（12）または（13）式 で評価できる。

（3）樹脂サンドイッチ鋼板.の座屈応力度および後座屈 強度は, 幅厚比の他, 樹脂厚比, 樹脂のせん断弾性係数 比の影響を受ける。

（4）樹脂サンドイッチ鋼板の弾性座屈強度, 後座屈強 度は，同一厚さの普通鋼板に比へ低く，その低下率は樹 脂厚比が大きいほど，また幅厚比が小さいほど大きい。

（5）樹脂層のせん断弾性係数が及ぼす影響は, 幅厚比 が大きいほよ゙大きい。

\section{6. あとがき}

3 節の実験は, 建設省新素材総プロの一環である制振 鋼板利用技術小委員会構造グループ（(社) 鋼材俱楽部, ステンレス協会, 恶鉛鉄板会) の研究活動の一部として 行われたものであり，同委員会の合意を得て本論文に揭 ・載した。関係各位の御厚意に謝意を表する。

\section{Appendix-1}

文献1）によれば，3点曲げを受ける樹脂サンドイッチ鋼板の スパン中央の変位は, 次式で与えられる。(記号は，Fig.a を参 照)

$$
\begin{aligned}
& 2 \mathbb{P} \\
& \begin{array}{|l|l|}
\hline 0 & 0 \\
+1 p & 1 p \\
\hline 1 t & 1 t \\
\hline
\end{array} \\
& 21_{\mathrm{p}}=100 \mathrm{~mm} \\
& \text { Fig. a 三点曲げ試験 } \\
& u=\frac{I_{D}^{3}}{3 D_{11}}\left\{1+f_{v} C_{v}\right\} \\
& \left.C_{v}=\left[1-\frac{\tanh \left(\xi l_{p}\right)}{\xi l_{p}} \mid(q-1)\left(\cos \left(\xi l_{p}\right)-1\right)^{2}+1\right\}\right] \\
& \left(\xi l_{\rho}\right)^{2}=\left(\frac{12 l_{p}}{3 T}\right)^{2} \frac{G_{c} \varphi_{v}}{E_{s}} \\
& \text { ここに, } \\
& D_{11}=\frac{E_{s} T^{3}}{12}\left\{1-(1-\tilde{E}) \beta^{3} \mid, \quad \beta=t_{c} / T\right. \\
& f_{v}=\frac{9(1+\beta)^{2}}{(1-\beta)^{2}}, \quad \tilde{E}=E_{c} / E_{s} \\
& \varphi_{v}=\frac{1-\beta^{3}}{\beta(1-\beta)^{4}}, \quad q=\frac{\tanh \left(\xi l_{l}\right)}{\tanh \left(\xi l_{p}\right)}
\end{aligned}
$$

実験に使用した樹脂のせん断弹性係数は，上式を用いて次の 手順で算定した。すなわち (1) 樹脂サンドイッチ銅板の 3 点 曲げ試験の結果から（a）式を用い $C_{v}$ を算出，（2）(b) 式よ り $\xi l_{\rho}$ を算出， (3) さらに (c) を用い， $G / E$ を求める。この 時, (b) 式は, 双曲線関数を含むので， $\xi l_{\rho}$ に関する $C_{v}$ の数値 表を用意している。

\section{参考文献}

1）吉田総仁，本屋敷洋：樹脂サンドイッチ鎆板の 3 点曲げ の弹塑性解析, 塑性之加工, Vol. 30, No. 340, pp.716 。 $722,1989.5$

2）牧野内昭武：弾塑性有限要素法による板材の平面ひする U曲げの解析, 塑性と加工, Vol.27, No. 301, pp. 301 306, 1986.2

3）牧野内昭武, 吉田 茂, 小川秀夫: 弾塑性有限要素法に よる樹脂複合鋼板の曲げ形成過程のシミュレーション, 塑性と加工, Vol. 29, No. 330, pp. 755 763, 1988.7

4）長井弘行, 塩田俊明, 西川 宙, 杉山茂好：制振鋼鈑製 屋根の強度と熱変形. CAMP-ISIJ, Vol.1.2，p. 351, 1989

5）建設省建築研究所：制振鋼鈑利用ガイドライン, pp. 56 $\sim 57,1991.3$

6) 川井忠彦, 大坪英臣: 平板の幾何学的非線形問題の一解 法, 日本造船学会論文集, 第 126 号, pp. $235 \sim 244$, 1969

7) Hardbord, R., Kroplin, B., ; Finite-Elementt-Methode zur nicht-linearen, Beulberechnung von Schalentragwerken, DerStahlbau, pp. 314 320, pp. 384 388, 1977.10 $/ 12$

8）加藤 勉：面内圧縮を受ける板の塑性崩壊について，日 本建築学会論文報告集, 第 107 号, pp. 37 42, 1965

9）田中義照，遠藤久芳：防㧥材の局部座屈を伴う防撓材の 圧縮強度, 日本造船学会論文集, 第 164 号, pp. 456 467, 1988

10) Tutomu Usami : Post-Buckling of Plates in Compression and Bending, ASCE, ST 3, pp. 591 609, March, 1982

11）上田幸雄, Sherif M. H. Rashed, 白点 基：大たわみを 伴う矩形板の組合わせ荷重に対する有効幅, 日本造船学 会論文集，第 159 号, pp. 425 438，1986

12) G. Winter: Strength of. Thin Steel Compression Flanges, Trans. of ASCE, Vol. 112, pp. 527 554, 1947

13）若林 實偏著; 鉄骨構造学詳論，丸善，12 章，1985

14）吉識雅雄：圧縮を受ける矩形平板の座屈限界の決定法の 一試案, 応用力学, 第一巻, 第三号, pp. 193 199, 1948

15) S.P. Timoshenko, J. M. Gere: Theory of Elastic Stability, 2 nd Edition, McGraw-Hill, Chapter 3, Chapter 7, 1936

(1992 年 9 月 3 日原稿受理, 1993 年 1 月 27 日採用決定) 